\title{
Hydrogen Peroxide for Insect and Algae Control in a Lettuce Hydroponic Environment
}

\author{
Vanessa Meireles Caixeta ${ }^{1}$, Adriano de Souza Pereira da Mata ${ }^{2}$, Carmen Rosa da Silva Curvêlo ${ }^{1}$, \\ Wagner de Souza Tavares ${ }^{2}$, Luiz Leonardo Ferreira ${ }^{3} \&$ Alexandre Igor Azevedo Pereira ${ }^{1}$ \\ ${ }^{1}$ Instituto Federal Goiano, Campus Urutaí, Urutaí, Goiás, Brazil \\ ${ }^{2}$ Asia Pacific Resources International Holdings Limited, Riau Andalan Pulp and Paper, Pangkalan Kerinci, Riau, \\ Indonesia \\ ${ }^{3}$ Centro Universitário de Mineiros, Mineiros, Goiás, Brazil \\ Correspondence: Alexandre Igor Azevedo Pereira, Instituto Federal Goiano, Campus Urutaí, Rodovia Geraldo \\ Silva Nascimento, Km 2.5, Fazenda Palmital, CEP: 75.790-000, Urutaí, Goiás, Brazil. Tel: 55-64-992-874-821. \\ E-mail: aiapereira@yahoo.com.br
}

Received: April 9, 2018

doi:10.5539/jas.v10n8p221
Accepted: May 29, $2018 \quad$ Online Published: July 15, 2018

URL: https://doi.org/10.5539/jas.v10n8p221

\begin{abstract}
Insects and algae demonstrate adaptability in hydroponic environments. Algae attract flies, Bradysia spp. (Diptera: Sciaridae) and Scatella stagnalis (Diptera: Ephydridae), called fungus gnats and shore fly, respectively. Flies feed on algae, damaging seedlings radicellae, and may transmit pathogens to lettuce plants. Little information on the management of flies and algae is known. A paradox in the face of the expansion of hydroponics. The objective was to evaluate the potential of hydrogen peroxide $\left(\mathrm{H}_{2} \mathrm{O}_{2}\right)$ as an insecticide and algaecide agent. Entomopathogenic fungi were also evaluated as an alternative control to flies. The experiment was conducted in a commercial hydroponic system under a randomized complete block design with 5 treatments and 4 replicates. The treatments, sprayed on the phenolic foam plates, immediately after lettuce seed deposition, were: $\mathrm{H}_{2} \mathrm{O}_{2}$, Beauveria bassiana, Metarhizium anisopliae, Spinosyn and water, as control. The quality of the lettuce seedlings (cv. Brida), the presence of flies and algae evolution in the phenolic foam plates were recorded daily. $\mathrm{H}_{2} \mathrm{O}_{2}$ and Spinosyn affected lettuce seed germination, but were able to reduce adult flies on the phenolic foam cells. The highest number of larvae was observed with both fungi, and only water, compared to $\mathrm{H}_{2} \mathrm{O}_{2}$. No larvae were found in Spinosyn sprayed phenolic foam cells. However, lettuce seedlings from Spinosyn sprayed plates were those with lower fresh weight. $\mathrm{H}_{2} \mathrm{O}_{2}$ severely retained algae infestation in phenolic foam cells over a 15-day observation period. The present work demonstrates the potential that $\mathrm{H}_{2} \mathrm{O}_{2}$ can play as an insecticidal and algaecide agent in hydroponic environments.
\end{abstract}

Keywords: fungus gnats, shore fly, $\mathrm{H}_{2} \mathrm{O}_{2}$, Beauveria, Metarhizium, Lactuca sativa, NFT hydroponics

\section{Introduction}

Food production with full attention to the modern demands of the market has been stimulating the vegetable productive chain in South America (Carvalho Filho \& Camargo, 2017). The search for better quality products with constant supply has led farmers to seek production systems obsessed with meeting these requirements, to obtain commercial advantages. As an example, Brazilian farmers sought to adapt to the production of organic vegetables as a way to meet the quality demanded by consumers. Public policy incentives have boosted the creation and establishment to date of this still expanding market niche (Dalcin et al., 2014). However, the problems in maintaining the constant supply of products due to the climatic influence exerted in certain regions and seasons, besides sources of biotic stress, have been a real obstacle (Blanc \& Kledal, 2012).

On the other hand, vegetable cultivation based on nutrient solutions (and therefore without soil) has found ample market space in capitals and countryside cities of Brazil (Costa \& Junqueira, 2000). The production of leaves and fruits with better quality, reduced employment of labor, early harvesting, besides the lower consumption of water and fertilizers are the advantages of hydroponic systems. The constant supply of food and without climate interference also justify its expansion, as well as the high possibility of adding value to the final product. On the 
other hand, pathogens, insects and algae can occur in agricultural greenhouses, demonstrating adaptability to this type of environment so simplified from the biological point of view (Lopes et al., 2000; Takikawa et al., 2015).

Algae are commonly present in the physical structures that make up the hydroponic system such as nutrient film technique (NFT) type. Higher labor costs and the need to temporarily scale up production to meet the frequent demand for food lead eventually to disregard of basic cleaning measures. Algae compete for nutrients, water and light with vegetables (Radin et al., 2009). Measures that reduce luminous incidence, such as the coverage of physical structures by plastic films, have been theoretically reported as efficient for algae control (Vännen \& Koskula, 1998). However, they require higher acquisition costs, time for meticulous application and high use of labor, making it impractical.

The presence of algae attracts two species of flies adapted to the hydroponic system, Bradysia spp. (Diptera: Sciaridae) and Scatella stagnalis (Diptera: Ephydridae) known as fungus gnats and shore fly, respectively. In warm seasons, their populations increase rapidly (Keates et al., 1989). These flies feed on algae and may inevitably damage the seedlings rootlets (Epenhuijsen et al., 2001). The role of these flies in horizontally transmitting pathogens to plants is also proven (Keates et al., 1989; El-Hamalawi, 2008; Radin et al., 2009). The association between algae, flies and pathogens may potentiate losses in the quantity and quality of food produced in hydroponic systems (Radin et al., 2009).

In view of this scenario, sanitizing agents and synthetic insecticides of wide spectrum have been used to control algae and flies, respectively, in an informal and non-technical way. The search for a multiple-use product that assists in the asepsis of physical structures and, at the same time, eliminates the infestation of flies in the hydroponic environment is urgent. The objective of this work was to evaluate the efficiency of hydrogen peroxide $\left(\mathrm{H}_{2} \mathrm{O}_{2}\right)$ as a sanitizing agent (for algae control) and insecticide (for fly control) in a hydroponic commercial system. $\mathrm{H}_{2} \mathrm{O}_{2}$ has a recognized potential for causing oxidative stress in living organisms (Vännin \& Koskula, 1998; Qin et al., 2011; Wojtyla et al., 2016) and is widely used as a disinfectant and sterilant (Watt et al., 2004). The evaluation of entomopathogenic fungi to replace synthetic insecticides, in the control of fungus gnats and shore fly, was also explored as a more sustainable form of fly control (Stanghellini \& El-Hamalawi, 2005) and other vector insects (Tiago et al., 2014), in a hydroponic system.

\section{Methods}

The experiment was conducted in a commercial hydroponic system, focusing on lettuce production, located in the municipality Pires do Rio, state of Goiás $\left(17^{\circ} 17^{\prime} 59^{\prime \prime} \mathrm{S}, 48^{\circ} 16^{\prime} 46^{\prime \prime} \mathrm{W}\right.$ and $758 \mathrm{~m}$ altitude). The mean temperature was $24.5 \pm 3.5^{\circ} \mathrm{C}$ and the mean relative humidity was $60 \pm 15 \%$, both inside the greenhouse. Pires do Rio climatic type is tropical semi-humid (tropical-AW), by Köppen classification, being warm in spring and summer, and mild in autumn and winter.

The greenhouse (Hidrogood ${ }^{\circledR}$ model) (Taboão da Serra, São Paulo state, Brazil), where the experiment was conducted, was installed with the longitudinal axis in the east-west direction to reduce the internal shading. Polypropylene arches, plastic film on the roof (150 $\mu$, added against ultraviolet rays) and sombrite type screen on the lateral side constituted the greenhouse physical structure. The total dimensions of the greenhouse were $5 \mathrm{~m}$ high (right foot), $50 \mathrm{~m}$ wide and $100 \mathrm{~m}$ long.

The lettuce cultivar Brida (Hortec Tecnologia de Sementes Ltda) (Bragança Paulista, São Paulo state, Brazil) was used. This cultivar produces large and vigorous adult plants, with leaves peeled at the edges of medium green color and with brightness. The cultivar Brida is recommended for the summer season, but can be planted in other seasons of the year, either in the field or hydroponics. It possesses an excellent pattern, large number of leaves, uniform crop and is tolerant to early tossing as well as burning the edges. The cycle from germination to harvesting is 60 to 70 days. It has high resistance to Lettuce Mosaic Virus (LMV) (Potyvirus, Potyviridae), moderate resistance to septoriosis (Septoria lactucae) (Mycosphaerellaceae) and resistance to edge burning.

The area used for lettuce seed germination was composed of a germination table with $1.15 \mathrm{~m}$ of height of the floor, $30 \mathrm{~m}$ of length and $3 \mathrm{~m}$ of width, with capacity for 100 phenolic foam plates. The table was composed of six aluminum channels, $5 \mathrm{~cm}$ wide, $30 \mathrm{~m}$ long and spaced each $60 \mathrm{~cm}$. Plastic trays $(60 \times 40 \mathrm{~cm}), 1 \mathrm{~cm}$ deep, were used to support each phenolic foam plate on the aluminum gutters. The slope of the table was $3 \%$. Only the germination area of the greenhouse was necessary for installation and the conduct of the experiments, and there was no need to use the nursery and hydroponic growth areas.

The sowing was done with the aid of a manual seeder tray, for pelleted seeds, where only one lettuce seed per cell $(2 \times 2 \times 2 \mathrm{~cm}$ in cubic size $)$ was deposited. The phenolic foam plates contained 345 cells each. After sowing, each phenolic foam board containing the seeds was covered with a cloth moistened above the seed level to 
maintain humidity and shading for three consecutive days or until germination, which was observed visually daily. The plates were irrigated for five consecutive days after sowing with potable water and then with a daily nutrient solution (Bezerra Neto et al., 2010).

After deposition of lettuce seeds on the phenolic foam plates, therefore, before the germination, the treatments were sprayed and constituted by hydrogen peroxide $\left(\mathrm{H}_{2} \mathrm{O}_{2}\right)$ (T1), Beauveria bassiana (T2), Metarhizium anisopliae (T3), Spinosyn (T4) and water as a control (T5). Two liters of $\mathrm{H}_{2} \mathrm{O}_{2}$ were used for 100 liters of water and then the solution $\mathrm{pH}$ was adjusted (for $\mathrm{pH} 6.5$ ) with phosphoric acid $(10 \mathrm{~mL} / 100 \mathrm{~L}$ ). The dose of B. bassiana was $50 \mathrm{~g} / 20 \mathrm{~L}$ of water, while for $M$. anisopliae $17 \mathrm{~g} / 20 \mathrm{~L}$ of water. The insecticide Spinosyn was applied in the dose of $10 \mathrm{~mL} / 1 \mathrm{~L}$ of water. The doses were adjusted to a $2 \mathrm{~L}$ container where the phenolic foam plates containing the lettuce seeds were manually sprayed, only once. Each phenolic foam plate received one liter of solution, respecting the treatments.

The experiment followed a randomized complete block design, with five treatments and four replicates. On the fourth day after sowing, lettuce seed germination was started, which lasted 15 days in succession (time required by the cultivar for transplanting) and at similar daily schedules (17:00 hours). The number of adult flies landed on the plates was visually recorded daily from the germination of the seeds. At that time, there was no distinction between the two species of adult flies because of their apparent visual similarity.

Soon after the $15^{\text {th }}$ day, all four phenolic foam plates (replicates), by treatment, containing lettuce seedlings, were transferred to a laboratory located at the Instituto Federal Goiano, Urutaí Campus (Urutaí, Goiás, Brazil), where the number of larvae present per plate was recorded. At the time, all 345 cells per plate were individually separated and cut with a hand-styled pen into 10 cross-sections of equal size to observe the presence of fungus gnats and shore fly larvae. In this stage differentiation between the two species of flies occurred due to the easily detectable morphological differences. Despite the destructive analyzes, lettuce seedlings present in each cell were preserved to quantify immediately their fresh weight $(\mathrm{mg})$. The evolution (in days) of the incidence of algae in the cells of the phenolic foam plates was counted from the deposition of lettuce seeds on the cells. A scale with five different grades was suggested to diagnose the presence (or not) of algae as well as their quantity. For this, a ranking of $0,25,50,75$ and $100 \%$ of the cells with presence of algae was used.

The comparison between treatments for the lettuce seeds accumulated germination was performed through regression figures, considering the time interval as an important information measure on the germination dynamics in vegetables (Ranal \& Santana, 2006). In this case, the best fit model was the sigmoid type $(y=a /\{1$ $\left.\left.+\exp \left[-\left(\mathrm{x}-\mathrm{x}_{0}\right) / \mathrm{b}\right]\right\}\right)$. Several regression models were previously compared through their visual behavior and additionally through the $\mathrm{R}^{2}$ values obtained by the SigmaPlot ${ }^{\mathbb{B}}$ software version 11 (Systat Software Inc). The same procedure was performed for the independent variable adult flies landed on the plates. In this case, the regression of the exponential type (Stirling model) $\left(y=y_{0}+a \cdot[\exp (b \cdot x)-1] / b\right)$ was the one that presented the best fit for representing the treatments.

Data regarding the number of larvae present on the plates followed normal distribution and, therefore, an analysis of variance was performed to diagnose the existence of difference (or not) between treatments. After this previous diagnosis, the means of the treatments were compared to each other through the Tukey's test at 5\% probability. The same procedure was performed in the independent variable seedling fresh weight.

To compare the evolution of algae infestation in the phenolic foam plates, as a function of the treatments, a visual analysis was presented graphically through mean infestation (\%) per treatment as a function of days after sowing. As the evolution data of algae infestation did not follow a normal distribution, the Kruskal-Wallis non-parametric test was used. In this case, we verified if at least one sample stochastically dominated another sample, that is, if there was a difference between treatments. The evolution of algae in an illustrative manner was maintained to facilitate the visualization of the differences between treatments (and throughout the evaluation days), since the Kruskal-Wallis test does not identify where stochastic dominance occurs or for how many pairs of groups such dominance is obtained.

\section{Results}

The percentage of lettuce seeds germinated, during the time interval, was influenced by the treatments (Figure 1). Sigmoidal regression models described with better adjustments the daily seed germination behavior, as a function of the treatments (Figure 1). The values of $\mathrm{R}^{2} ; \mathrm{F}$ and $P$ that describe the fit of the germination data obtained for the sigmoidal regression model were, respectively, 99.69; 1772.31 and $<0.0001\left(\right.$ to $\left.\mathrm{H}_{2} \mathrm{O}_{2}\right), 99.43$; 953.78 and $<0.0001$ (to B. bassiana), 98.72; 425.63 and $<0.0001$ (to M. anisopliae), 99.20; 686.15 and < 0.0001 (to Spinosyn) and $99.61 ; 1419.11$ and $<0.0001$ (to water). Four days after sowing, only $27 \%$ and $25.7 \%$ of the seeds had germinated in the sprayed treatments with hydrogen peroxide and Spinosyn, respectively. At the 
same time, the germination values were $46.8 \%, 55.40 \%$ and $53.80 \%$ for B. bassiana, M. anisopliae and water, respectively (Figure 1). The germination values of the lettuce seeds submitted to hydrogen peroxide treatments and Spinosyn were kept below the other treatments until the $15^{\text {th }}$ day after sowing. The mean values for lettuce seed germination were $69.96 \%( \pm 7.91)$ for hydrogen peroxide, $77.61 \%( \pm 8.93)$ for B. bassiana, $79.18 \%( \pm 7.78)$ for M. anisopliae, $65.45 \%( \pm 8.90)$ for Spinosyn and $78.77 \%( \pm 8.15)$ for water.

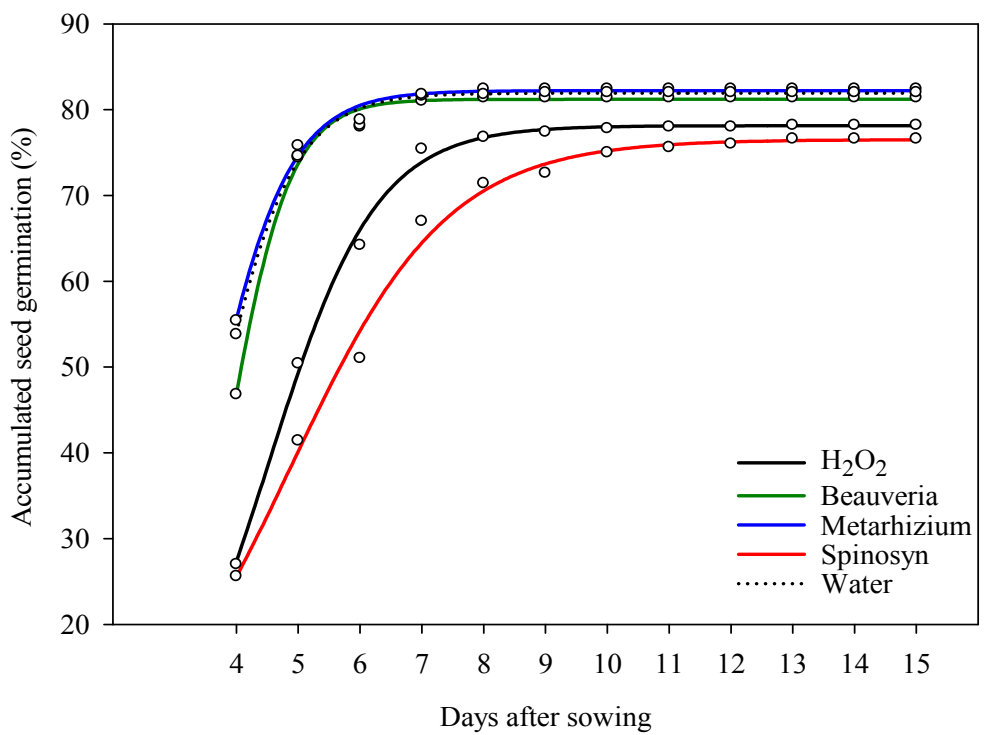

Figure 1. Observed values (circles) and estimated (colored and dotted lines), using a sigmoidal regression model, for the accumulated germination of lettuce seeds (Brida cultivar) over time (days after sowing). The germination plates, containing one seed per cell, were sprayed with $\mathrm{H}_{2} \mathrm{O}_{2}$ (T1), Beauveria bassiana (T2), Metarhizium anisopliae (T3), Spinosyn (T4) and Water (T5)

The treatments $\mathrm{H}_{2} \mathrm{O}_{2}$ (T1) and Spinosyn (T4) were able to reduce the presence of adult fungus gnats and shore fly observed in landing activity on the phenolic foam plates (Figure 2). However, in the treatments B. bassiana, $M$. anisopliae and water the number of adult flies landed in the plates was superior in three times in comparison with the treatments T1 and T4 (Figure 2). The number of flies landed in the phenolic foam plates, depending on the treatments, was adjusted to the exponential regression model (Stirling model) with the following parameters for the regression curves and, therefore, model choice: hydrogen peroxide $\left(\mathrm{R}^{2}=96.13, \mathrm{~F}=175.10\right.$ and $P<$ $0.0001)$, B. bassiana $\left(\mathrm{R}^{2}=92.06, \mathrm{~F}=82.19\right.$ and $\left.P<0.0001\right), M$. anisopliae $\left(\mathrm{R}^{2}=93.92, \mathrm{~F}=109.10\right.$ and $P<$ $0.0001)$, Spinosyn $\left(\mathrm{R}^{2}=98.05, \mathrm{~F}=352.13\right.$ and $\left.P<0.0001\right)$ and water $\left(\mathrm{R}^{2}=94.35, \mathrm{~F}=117.87\right.$ and $\left.P<0.0001\right)$. 


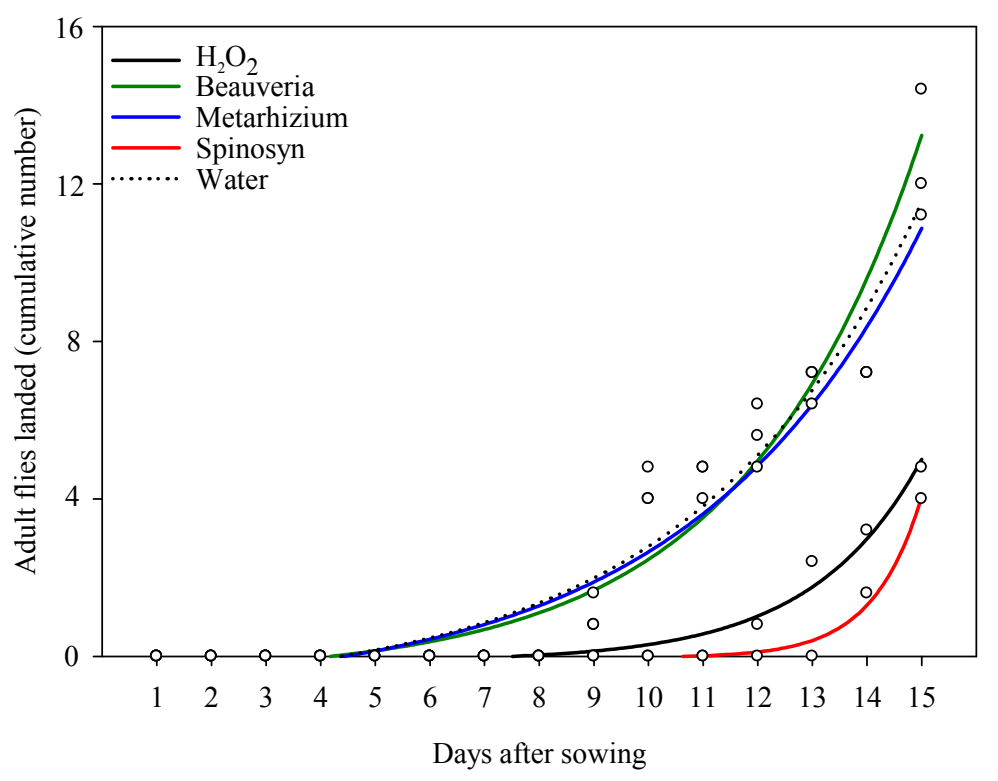

Figure 2. Cumulative total of adult flies of fungus gnats and shore fly landed by phenolic foam board, through an exponential regression model with observed values (circles) and estimated (colored and dotted lines) over time

(days after sowing). The germination plates, containing one seed per cell, were sprayed with $\mathrm{H}_{2} \mathrm{O}_{2}$ (T1), Beauveria bassiana (T2), Metarhizium anisopliae (T3), Spinosyn (T4) and Water (T5)

The number of shore fly larvae $(P=0.03)$ and fungus gnats $(P=0.04)$ present inside the cells of the phenolic foam plates varied according to the treatments evaluated (Figure 3). The B. bassiana treatment was the one where the largest number of shore fly larvae was observed (mean of $304.00 \pm 18.00$ larvae per plate) followed by

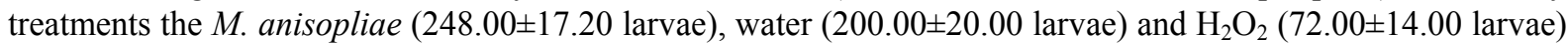
(Figure 3). The treatment that provided the largest amount of fungus gnats larvae was the one where the plates

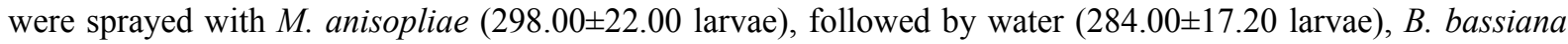
(132.00 \pm 14.00 larvae) and $\mathrm{H}_{2} \mathrm{O}_{2}(24.00 \pm 4.00$ larvae) (Figure 3). For both species of flies, no larva was found when phenolic foam plates were sprayed with Spinosyn (Figure 3). 


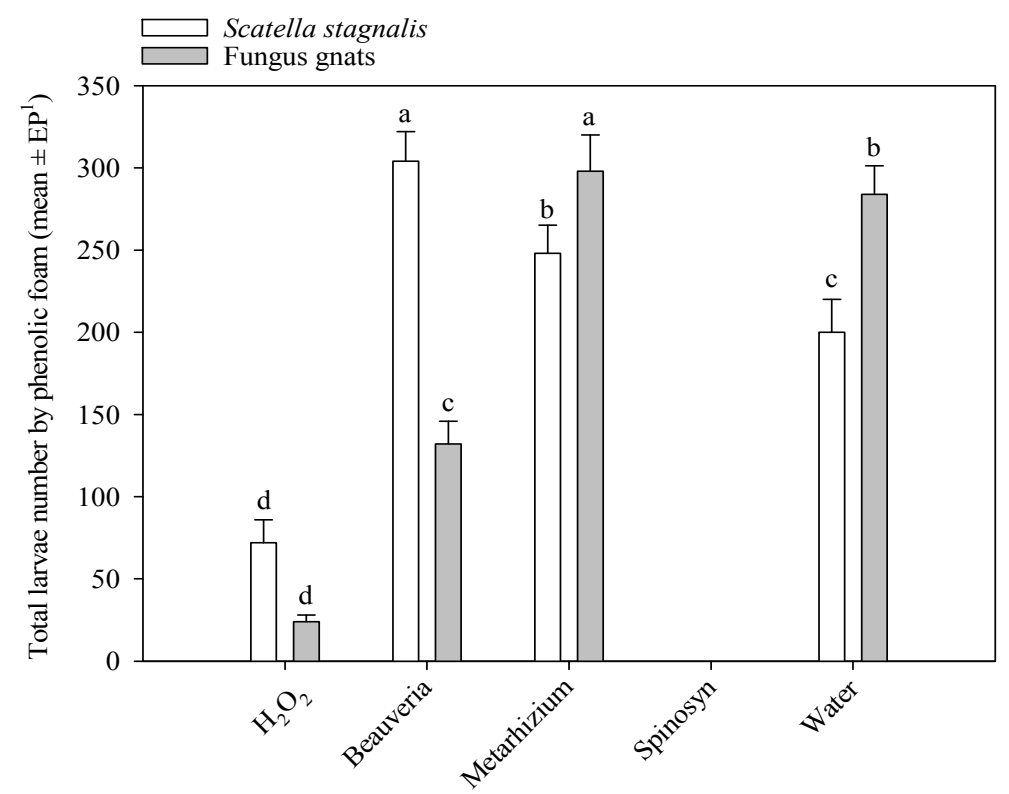

Figure 3. Total larvae (mean \pm EP1) of shore fly and fungus gnats found by foam board sprayed with $\mathrm{H}_{2} \mathrm{O}_{2}$ (T1), Beauveria bassiana (T2), Metarhizium anisopliae (T3), Spinosyn (T4) and Water (T5). Means followed by the same letter, for each species of fly, do not differ among themselves at the $5 \%$ probability level by the Tukey's test

The fresh weight of lettuce seedlings was influenced by treatments $(P=0.03)$ (Figure 4). The lettuce seedlings from Spinosyn sprayed plates were those with the lowest fresh weight $(0.65 \pm 0.10 \mathrm{mg})$ at the end of the evaluation period. For the other treatments, lettuce fresh weight did not vary (Figure 4).

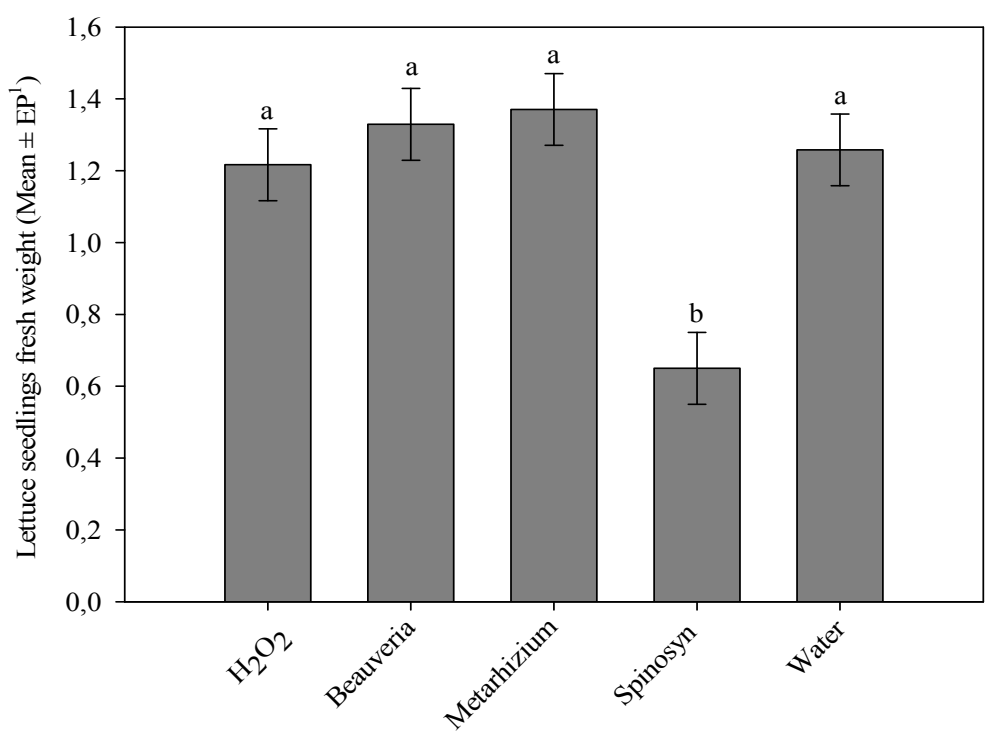

Figure 4. Fresh weight (Mean \pm EP1) of lettuce seedlings (Brida cv.) Sprayed, prior to germination, with $\mathrm{H}_{2} \mathrm{O}_{2}$ (T1), Beauveria bassiana (T2), Metarhizium anisopliae (T3), Spinosyn (T4) and Water T5). Means followed by the same letter do not differ from each other at the 5\% probability level by the Tukey's test

The use of the scale of notes for the incidence of algae in cells of phenolic foams has been shown to be useful for observing the evolution of infestation over time (Figure 5A). In all treatments, there was an increase in the presence of algae in the phenolic foam cells over time, with initial values starting from $0 \%\left(1^{\text {st }}\right.$ day after sowing) to $100 \%\left(15^{\text {th }}\right.$ day after sowing $)$. 


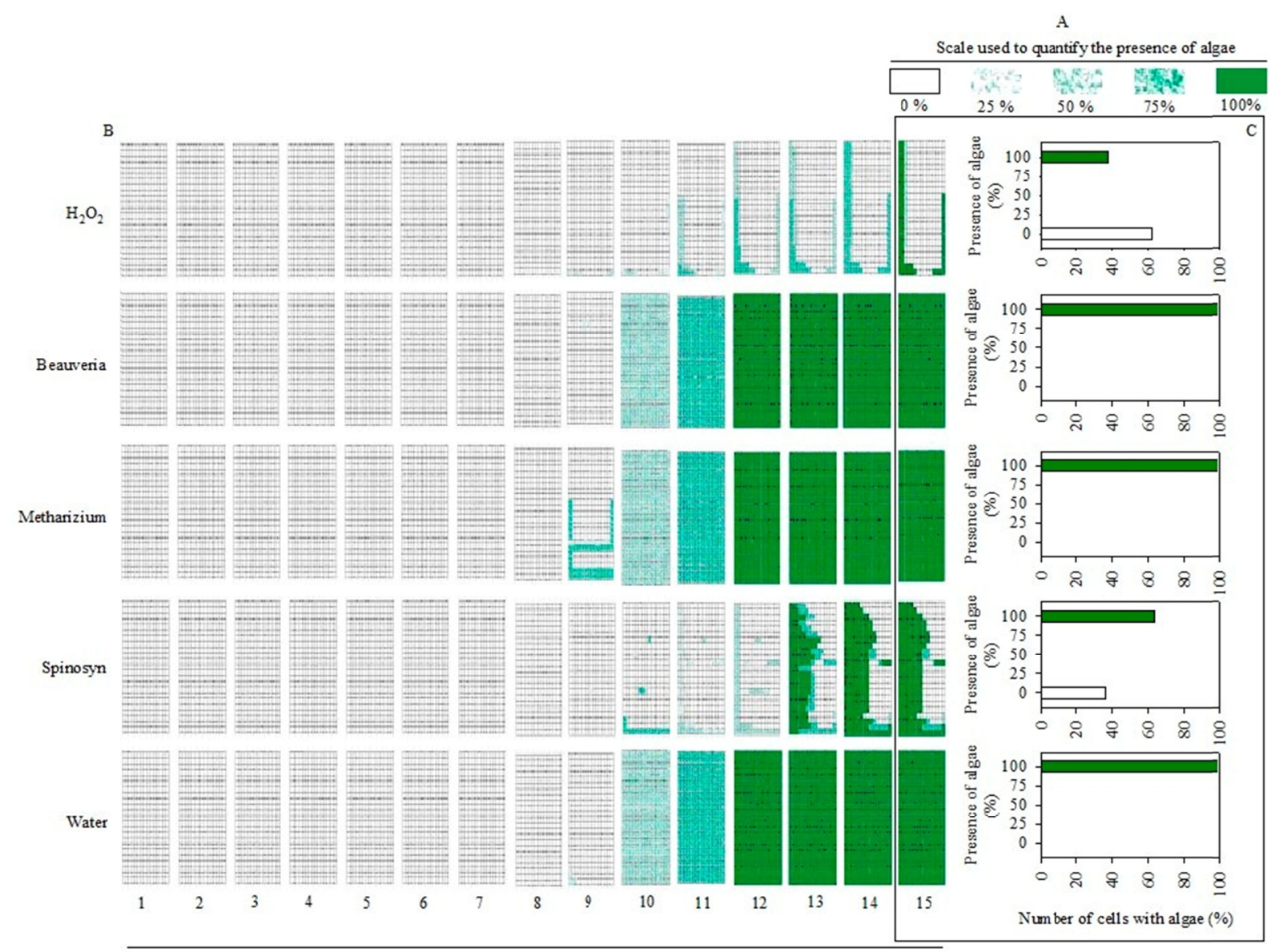

Days after sowing

Figure 5. Scale adopted to quantify the presence of visible algae on the surface of the cells, per plate ( 345 cells) of phenolic foam (Figure 5A). Evolution of algae infestation on phenolic foam plates for treatments $\mathrm{H}_{2} \mathrm{O}_{2}(\mathrm{~T} 1)$,

Beauveria bassiana (T2), Metarhizium anisopliae (T3), Spinosyn (T4) and Water (T5) as a function of time (days after sowing) (Figure 5B). Quantification (\%) of the number of cells infected with algae, by treatment, only, for the last day of the evaluation (15th day) (Figure 5C)

The period of onset of algal colonization began on the $9^{\text {th }}$ day after sowing, mainly in the treatment where the fungus $M$. anisopliae was previously sprayed (Figure 5B). There was a significant difference for the algae infestation between treatments in the $9^{\text {th }}(\mathrm{H}=89.32, \mathrm{P}=0.02), 10^{\text {th }}(\mathrm{H}=101.23, \mathrm{P}=0.01), 11^{\text {th }}(\mathrm{H}=90.12, \mathrm{P}(\mathrm{H}$ $=98.21, \mathrm{P}=0.001)$, and the $15^{\text {th }}$ day after sowing $(\mathrm{H}=112.29, \mathrm{P}=0.001), 13(\mathrm{H}=113.76, \mathrm{P}=0.004)(\mathrm{H}=$ $130.40, \mathrm{P}<0.05)$. In Figure $5 \mathrm{C}$ the final number $(\%)$ of cells infested with algae was explored through vertical bar charts, focusing on the last day of the evaluation $\left(15^{\text {th }}\right.$ day after sowing). For the hydrogen peroxide treatment, $62.31 \pm 2.30 \%$ of the phenolic foam plate did not contain algae (Figure 5C). For the treatment with Spinosyn $36.23 \pm 5.21 \%$ of the cells also had no presence of algae (Figure 5C). However, in the other treatments (the two entomopathogenic fungi and water) all cells present in the phenolic foam plates reached $100 \%$ of algae infestation (Figure 5C).

\section{Discussion}

$\mathrm{H}_{2} \mathrm{O}_{2}$ has been used for several purposes, but it stands out as a disinfectant and sterilizing agent (Watt et al., 2004). Its use in hydroponic systems for purposes of cleaning physical structures is still limited in comparison to other oxygenated compounds, such as $\mathrm{NaOH}$ and $\mathrm{KOH}$ (Bezerra Neto et al., 2010). The use of $\mathrm{H}_{2} \mathrm{O}_{2}$ as an insect control agent is also sporadically investigated, especially in greenhouses. In the present study, $\mathrm{H}_{2} \mathrm{O}_{2}$ reduced the number of adult flies and the number of larvae present in phenolic foam cells due to their potential to cause oxidative stress in living organisms (Zhang et al., 2016). In addition, $\mathrm{H}_{2} \mathrm{O}_{2}$ contained drastically the evolution of algal growth on the plates, thus, reducing colonization by fungus gnats and shore fly, which are commonly 
associated with algae incidence (Keates et al., 1989; Vänninen \& Koskula, 1998). These results indicate the potential of $\mathrm{H}_{2} \mathrm{O}_{2}$ as a control agent for these flies, as well as algae in hydroponic lettuce production systems.

Despite the advantages described above, $\mathrm{H}_{2} \mathrm{O}_{2}$ interfered with the germination of lettuce seeds. Cucumber seedlings showed lower growth immediately after exposure to higher doses of hydrogen peroxide (125 ppm) but recovered from phytotoxicity days later (Vänninen \& Koskula, 1998). The concentration used and the phenological stage of the plant at the time of exposure may unexpectedly modify the status of $\mathrm{H}_{2} \mathrm{O}_{2}$ as a molecule toxic (or not) to vegetables (Wojtyla et al., 2016). Oxygenated compounds are highly reactive molecules with oxidative potential, which makes them capable of interacting with various biomolecules present in plant seeds (including nucleic acids, proteins and lipids) (Wojtyla et al., 2016). Thus, lettuce seeds exposed to $\mathrm{H}_{2} \mathrm{O}_{2}$ may have suffered cell damage due to oxidative stress. The actual effects of hydrogen peroxide on plant physiology have been the subject of debate in the last decades, with results indicating benefits of this molecule by increasing resistance against sources of abiotic stress (e.g., saline stress) (Niu \& Liao, 2016). To further elucidate the effect of $\mathrm{H}_{2} \mathrm{O}_{2}$ exposure on germination in lettuce seeds, a work focused on the dilution of this molecule through dose-response investigations is under way.

The negative interference of the Spinosyn insecticide under lettuce (mainly on seed germination and fresh weight of seedlings) proves that insecticides can affect the development of non-target organisms, including vegetables (DeLorenzo et al., 2001). This justification also applies to the fact that this insecticide has retarded the growth of algae in the phenolic foam plates over time. The exposure time (immediately after sowing) may have potentiated its toxic effect, as observed by Shakir et al. (2015) in tomato seeds. This demonstrates the seed sensitivity to insecticide exposure. On the other hand, the dry weight of the flowers, peduncles, leaves and roots of Gerbera jamesonii (Asteraceae) exposed to Spinosyn (concentrations of $1 \times$ and $4 \times$ more than that recommended) were not affected when the insecticide was applied to the seedlings (Spiers et al. 2006). Shakir et al. (2015) also observed that low concentrations of insecticides stimulated the germination of tomato seeds, while high doses acted as inhibitors. Thus, due to the complexity of factors potentially capable of interfering with the germination of lettuce seeds, we suggest that applications of insecticides to control insect pests in hydroponic systems should be avoided in the initial stages (such as seeds). Infestations by fungus gnats and shore fly are associated with the presence of algae (Keates et al., 1989). Therefore, as the presence of algae on the plates started from the $8^{\text {th }}$ day after sowing, perhaps this would be a safer period for the application of insecticides in a preventive way for control purposes of the flies, reducing the risk of side-effects to the seeds.

The spinosyn insecticide, derived from secondary metabolites synthesized by soil actinomycetes, is approved for use in organic systems of agricultural production to control thrips, Lepidoptera and flies (Weintraub et al., 2017). However, it has been defined as broad-spectrum because its site of action is the insect nervous system (Salgado et al., 1998). Biopesticides that act as insect growth regulators have been more specific and therefore, widely used in greenhouses (Weintraub et al., 2017). This may prevent the negative effect of insecticides on non-target organisms, be they invertebrates or plants. Populations of natural enemies may be present in natural hydroponic systems (Vännen \& Koskula, 1998) or through artificial releases (Gerson \& Weintraub, 2007), which emphasizes the real need to use more selective insecticides.

The two entomopathogenic fungi evaluated were innocuous to seed germination and lettuce seedlings fresh weight. However, they were not efficient in controlling both adult and larval fly species, nor to control algal evolution in phenolic foams. Similar results were observed by Andreadis et al. (2016). According to these authors, B. bassiana (GHA strain) showed no interference in the production of the champignon-type mushroom Agaricus bisporus (Agaricaceae), nor in the control of fungus gnats in the larval and adult stages. In contrast to our results and those described by Andreadis et al. (2016), Stanghellini and El-Hamalawi (2005) observed high mortality of shore fly larvae and adults exposed to Beauveria bassiana. In this case, the authors identified and isolated a strain previously found in adult shore fly corpses. (1) Simplification of the environment where this assay was conducted (exposure of insects kept in Petri dishes) and (2) prior selection of a highly virulent $B$. bassiana strain may have influenced the high mortality found.

Despite the lack of efficiency for fungus gnats and shore fly observed, the microbiological control of pests present in hydroponic systems can generate many new perspectives, such as the substitution of insecticide usage. Other insect groups, such as thrips and aphids, presented greater susceptibility to B. bassiana and M. anisopliae (Fournier \& Brodeur, 2000; Lopes et al., 2000). Metarhizium anisopliae (isolate 1104) demonstrated an efficiency of $60 \%$, six days after the first spray, on Frankliniella occidentalis (Thysanoptera: Thripidae) in hydroponic system trials (Lopes et al., 2000). The simultaneous use of $\mathrm{H}_{2} \mathrm{O}_{2}$ (our most efficient treatment) and entomopathogenic fungi, in hydroponic systems, can become a reality when it comes to pest insect control. Zhang et al. (2016) demonstrated that $\mathrm{H}_{2} \mathrm{O}_{2}$ can increase the production of mycotoxins and, therefore, the 
virulence in $B$. bassiana, due to the stimulus triggered by oxidative stress. This suggests the existence of a possible compatibility between the treatments evaluated in the present work. However, the effect of this probable synergy needs to be suitably tested in the management of fungus gnats and shore flies.

Problems with the presence of algae and, consequently, disturbances in fly populations can be drastically controlled if all recommended hygiene procedures are practiced (Epenhuijsen et al., 2001). However, this premise is difficult to implement in commercial hydroponic systems, due to the expense of labor required and frequent production overlapping. This requires the need to use products with various biological functions (such as disinfection and pesticide). The present work demonstrated the potential that $\mathrm{H}_{2} \mathrm{O}_{2}$ can play in hydroponic systems as a sanitizing and controlling agent for fungus gnats and shore flies. These insects are commonly present in the phenolic foams used as substrate for germination of lettuce seeds. Possible future problems can also be addressed with routine use of $\mathrm{H}_{2} \mathrm{O}_{2}$, since flies are horizontal transmitters of plant pathogens (El-Hamalawi, 2008) and by the fact that investigations demonstrated the antifungal action of hydrogen peroxide (Qin et al., 2011).

\section{Conclusions}

$\mathrm{H}_{2} \mathrm{O}_{2}$ and Spinosyn affected lettuce seed germination, but were able to reduce the presence of adult flies on the phenolic foam cells. The highest number of larvae flies was observed with both fungi, and only water, compared to $\mathrm{H}_{2} \mathrm{O}_{2}$. No larvae were found in Spinosyn-sprayed phenolic foam cells. However, the lettuce seedlings from Spinosyn sprayed plates were those with lower fresh weight. $\mathrm{H}_{2} \mathrm{O}_{2}$ severely retained algae infestation in phenolic foam cells over a 15-day observation period.

\section{Acknowledgements}

To Mr. Gilber Paulo dos Santos Abadia, owner of hydroponics where the work was conducted. To CNPq for the granting of financial assistance. The Foundation for Research Support of the state of Goiás (FAPEG). To the PAPPE Program of the Instituto Federal Goiano that granted a research grant to Alexandre IA Pereira (Process $\mathrm{n}^{\circ}$ 23216.000570/2017-26). And, finally, to Instituto Federal Goiano for the structural support for the execution of this work.

\section{References}

Andreadis, S. S., Cloonan, K. R., Bellicanta, G. S., Paley, K., Pecchia, J., \& Jenkins, N. E. (2016). Efficacy of Beauveria bassiana formulations against the fungus gnat Lycoriella ingénue. Biological Control, 103, 165-171. https://doi.org/10.1016/j.biocontrol.2016.09.003

Bezerra Neto, E., dos Santos, R. L., Pessoa, P. M. de A., Andrade, P. K. B. de, Oliveira, S. K. G. de, \& Mendonça, I. F. de. (2010). Tratamento de espuma fenólica para produção de mudas de alface. Revista Brasileira de Ciências Agrárias, 5, 418-422. Retrieved from http://www.redalyc.org/articulo.oa?id=119016971022

Blanc, J., \& Kledal, P. R. (2012). The Brazilian organic food sector: Prospects and constraints of facilitating the inclusion of smallholders. Journal of Rural Studies, 28, 142-154. https://doi.org/10.1016/j.jrurstud.2011. 10.005

Camargo Filho, W. P., \& Camargo, F. P. (2017). A quick review of the production and commercialization of the main vegetables in Brazil and the world from 1970 to 2015. Horticultura Brasileira, 35, 160-166. https://doi.org/10.1590/s0102-053620170202

Costa, J. S., \& Junqueira, A. M. R. (2000). Diagnóstico do cultivo hidropônico de hortaliças na região do Distrito Federal. Horticultura Brasileira, 18, 49-52. https://doi.org/10.1590/S0102-05362000000100011

Dalcin, D., Souza, A. R. L. de, Freitas, J. B. de, Padula, A. D., \& Dewes, H. (2014). Organic products in Brazil: From an ideological orientation to a market choice. British Food Journal, 116, 1998-2015. https://doi.org/ 10.1108/BFJ-01-2013-0008

DeLorenzo, M. E., Scott, G. I., \& Ross, P. E. (2001). Toxicity of pesticides to aquatic microorganisms: A review. Environmental Toxicology and Chemistry, 20, 84-98. https://doi.org/10.1002/etc.5620200108

El-Hamalawi, Z. A. (2008). Acquisition, retention and dispersal of soilborne plant pathogenic fungi by fungus gnats and moth flies. Annals of Applied Biology, 153, 195-203. https://doi.org/10.1111/j.1744-7348.2008. 00247.x

Epenhuijsen, C. W. V., Page, B. B. C., \& Koolaard, J. P. (2001). Preventative treatments for control of fungus gnats and shore flies. Horticultural Insects. New Zealand Plant Protection, 54, 42-46. Retrieved from http://www.nzpps.org/terms_of_use.html 
Fournier, V., \& Brodeur, J. (2000). Dose response susceptibility of pest aphids (Homoptera: Aphididae) and their control on hydroponically grown lettuce with the entomopathogenic fungus Verticillium lecanii, Azadirachtin, and insecticidal soap. Environmental Entomology, 29, 568-578. https://doi.org/10.1603/ 0046-225X-29.3.568

Gerson, U., \& Weintraub, P. G. (2007). Mites for the control of pests in protected cultivation. Pest Management Science, 63, 658-676. https://doi.org/10.1002/ps.1380

Keates, S. E., Sturrock, R. N., \& Sutherland, J. R. (1989). Populations of adult fungus gnats and shore flies in British Columbia container nurseries as related to nursery environment, and incidence of fungi on the insects. New Forests, 3, 1-9. Retrieved from https://link.springer.com/article/10.1007/BF00128896

Lopes, R. B., Alves, S. B., \& Tamai, M. A. (2000). Fungo Metarhizium anisopliae e o controle de Frankliniella occidentalis em alface hidropônico. Scientia Agricola, 57, 239-243. https://doi.org/10.1590/S0103-9016200 0000200007

Niu, L., \& Liao, W. (2016). Hydrogen peroxide signaling in plant development and abiotic responses: Cross talk with nitric oxide and calcium. Frontiers in Plant Science, 7, Article 230. https://doi.org/10.3389/ fpls.2016.00230

Qin, G., Liu, J., Cao, B., Li, B., \& Tian, S. (2011). Hydrogen peroxide acts on sensitive mitochondrial proteins to induce death of a fungal pathogen revealed by proteomic analysis. PloS ONE, 6, e21945. https://doi.org/ 10.1371/journal.pone.0021945

Radin, B., Wolff, V. R. S., Lisboa, B. B., Witter, S., \& Silveira, J. R. P. (2009). Bradysia sp. em morangueiro. Ciência Rural, 39, 547-550. https://doi.org/10.1590/S0103-84782009000200036

Ranal, M. A., \& Santana, D. G. (2006). How and why to measure the germination process? Revista Brasileira de Botanica, 29, 1-11. https://doi.org/10.1590/S0100-84042006000100002

Salgado, V. L., Sheets, J. J., Watson, G. B., \& Schmidt, A. L. (1998). Studies on mode of action of Spinosad: The internal effective concentration and the concentration dependence of neural excitation. Pesticide Biochemistry and Physiology, 60, 103-110. https://doi.org/10.1006/pest.1998.2332

Shakir, S. K., Kanwal, M., Murad, W., Rehman, Z. U., Rehman, S. U., Daud, M. K., \& Azizullah, A. (2015). Effect of some commonly used pesticides on seed germination, biomass production and photosynthetic pigments in tomato (Lycopersicon esculentum). Ecotoxicology, 25, 329-341. https://doi.org/10.1007/ s10646-015-1591-9

Spiers, J. D., Davies Jr., F. T., He, C., Bográn, C. E., Heinz, K. M., Starman, T. W., \& Chau, A. (2006). Effects of insecticides on gas exchange, vegetative and floral development, and overall quality of Gerbera. HortScience, 41, 701-706. Retrieved from http://hortsci.ashspublications.org/content/41/3/701.abstract

Stanghellini, M. E., \& El-Hamalawi, Z. A. (2005). Efficacy of Beauveria bassiana on colonized millet seed as a biopesticide for the control of shore flies. HortScience, 40, 1384-1388. Retrieved from http://hortsci. ashspublications.org/content/40/5/1384.abstract

Takikawa, Y., Matsuda, Y., Kakutani, K., Nonomura, T., Kusakari, S., Okada, K., ... Toyoda, H. (2015). Electrostatic insect sweeper for eliminating whiteflies colonizing host plants: A complementary pest control device in an electric field screen-guarded greenhouse. Insects, 6, 442-454. https://doi.org/10.3390/ insects6020442

Tiago, P. V., Oliveira, N. T. de, \& Lima, E. A. L. A. (2014). Biological insect control using Metarhizium anisopliae: Morphological, molecular, and ecological aspects. Ciencia Rural, 44, 645-651. https://doi.org/ $10.1590 / \mathrm{S} 0103-84782014000400012$

Vanninen, I., \& Koskula, H. (1998). Effect of hydrogen peroxide on algal growth, cucumber seedlings and the reproduction of shore flies (Scatella stagnalis) in rockwool. Crop Protection, 17, 547-553. https://doi.org/ 10.1016/S0261-2194(98)00060-X

Watt, B. E., Proudfoot, A. T., \& Vale, J. A. (2004). Hydrogen peroxide poisoning. Toxicological Reviews, 23, 51-57. Retrieved from https://link.springer.com/article/10.2165\%2F00139709-200423010-00006

Weintraub, P. G., Recht, E., Mondaca, L. L., Harari, A. R., Diaz, B. M., \& Bennison, J. (2017). Arthropod pest management in organic vegetable greenhouses. Journal of Integrated Pest Management, 8, 1-14. https://doi.org/10.1093/jipm/pmx021 
Wojtyla, L., Lechowska, K., Kubala, S., \& Garnczarska, M. (2016). Different modes of hydrogen peroxide action during seed germination. Frontiers in Plant Science, 7, Article 66. https://doi.org/10.3389/fpls.2016. 00066

Zhang, C., Wang, W., Lu, R., Jin, S., Chen, Y., Fan, M., ... Hu, F. (2016). Metabolic responses of Beauveria bassiana to hydrogen peroxide-induced oxidative stress using an LC-MS-based metabolomics. Journal of Invertebrate Pathology, 137, 1-9. https://doi.org/10.1016/j.jip.2016.04.005

\section{Copyrights}

Copyright for this article is retained by the author (s), with first publication rights granted to the journal.

This is an open-access article distributed under the terms and conditions of the Creative Commons Attribution license (http://creativecommons.org/licenses/by/4.0/). 